\title{
A CASE REPORT ON CHRONIC RHINOSINUSITIS
}

KEY WORDS: Chronic Rhinosinusitis, Virechana, Avapeedanasyam.
Dr. Maya Mohan A*

\section{Dr. Smitha A V}

\section{Dr. Anuja. B}

Associate Professor, PNNM Ayurveda Medical College, Cheruthuruthy, Thrissur. *Corresponding Author

Associate Professor, PNNM Ayurveda Medical College, Cheruthuruthy, Thrissur.

Associate Professor, PNNM Ayurveda Medical College, Cheruthuruthy, Thrissur.

Chronic Rhinosinusitis is defined as persistent symptomatic inflammation of the nasal and sinus mucosa. Ayurvedic
treatments are very effective in the management of chronic sinusitis without any deleterious side effects than the
conventional treatment options like corticosteroids therapy and endoscopic sinus surgery. The present case 36 year old
cut lady, housewife, diabetic referred to Panchakarma OPD of PNNM Ayurveda Medical College with complaints of
recurrent episodes of head ache, occasional sneezing, post nasal dripping, nasal congestion and pain on back of eyes
since 1 year was diagnosed as Kaphaja sirasoola and managed for 3 months. Medicines with Virechana property and
Teekshna guna were selected to enhance mucociliary clearance and improve sinus drainage. So Avapeeda nasya with
Tulsi swarasa mixed with Madhu and Saindhavam was administered for 7 consecutive days followed by Anutaila
pratimarsa nasya till all the symptoms got relieved. After that Rasayana drugs were given. Follow up was done for 2 years.
Overall effect of therapies after the course of treatment showed complete remission and there was no recurrence.

\section{INTRODUCTION}

Chronic rhinosinusitis is an inflammation of the sinus or nasal passages occurring for more than 12 weeks at a time. It can be caused by infection, growth in sinuses (nasal polyp), swelling of lining of sinuses (respiratory tract infections or allergies). Mostly it is secondary to an unresolved upper respiratory tract infection, where muco ciliary clearance is affected. People with allergies and asthma are more vulnerable. The prevalence of CRS (chronic rhinosinusitis) measured in epidermiologic studies is 5\%-12\%. [1] Chronic rhinosinusitis is diagnosed clinically with a physical examination and focused sinonasal history. It is diagnosed when atleast two of the following four symptoms are present and occur for more than 12 weeks. (1) purulent nasal drainage (2) facial or dental pain (3) nasal obstruction (4) hyposmia. [2]

The sinus cavities allow air to be filtered during inhalation. For the antigens to be filtered and expelled, sinuses need to drain. Chronic inflammation can cause obstruction to the nasal passage, hinder drainage and lead to lower oxygen tension. This creates foci for bacteria to build up. Ciliary dysfunction or structural abnormalities can further exacerbate this process. [3]

Chronic sinusitis can be taken as kaphaja sirasoola mentioned by classical texts in Ayurveda. In Kaphaja sirasoola, there is loss of taste, feeling of heaviness of head, rigidity and cold, veins not pulsating, lassitude, pain mild during day and severe at nights, stupor, swelling of the eye sockets, itching in ears and vomitting . [4]

\section{CASE DESCRIPTION}

A 36 year old, housewife, moderately built came to the OPD of PNNM Ayurveda college with complaints of recurrent headache since 1 year, aggravated since 1 month. Also had complaints of pain and puffiness on the face and pain under the eyes more on left side. She had occasional sneezing since 1 year. Post nasal dripping and Nasal congestion also present causing difficulty in breathing. She also complaints of tiredness. Patient had a history of typhoid fever 1 year back. After that she had recurrent attack of throat pain, body pain, heaviness of head, acidity, head ache and occasional sneezing. At that time she used to take allopathic medication. Before 6 months, she had a viral fever attack. At that time also complaints got aggravated. She used to take bath in pond nearby but now she has stopped bathing in pond due these complaints, as she felt discomfort during these days. Heaviness of head increases on bending down the head and at night time. Episodes of headache usually occurs after exposure to cold climate or after travelling. Last one month all the complaints are aggravated and so she consulted an allopatic doctor, and they adviced for a course of antibiotic and to take CT scan. Seeing the report, he suggested for endoscopic sinus surgery. So she came to our hospital seeking alternative treatment.

Appetite was decreased. She used to take non vegetarian diet daily. Bowel-sometimes constipated, Sleep-now disturbed due to head ache.

Known diabetic since 5 years, under allopathic medication. No other medical or surgical history.

No history of similar complaints in family members

Systemic Examinations And Investigations

On inspection-puffiness of face more on left side

On examination-tenderness over maxillary, frontal sinus areas more on left.

Both inferior turbinate was inflamed more on left.

PLAIN CT SCAN OF PNS- impression-mucosal thickening in the bilateral maxillary, ethmoid air cells, bilateral frontal and sphenoid sinuses -possibly due to chronic sinusitis. [Figure 1]

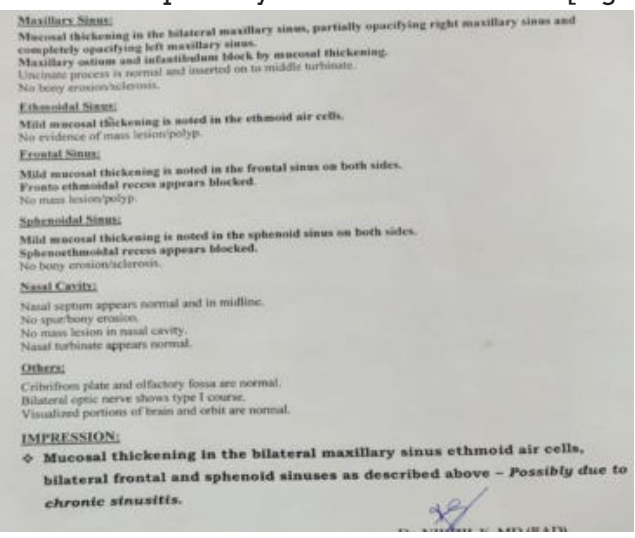




B.Therapeutic Interventions
Phase 1 From 7/6/2019-15/6/2019
Internal Medicines (table-1)
\begin{tabular}{|l|l|}
\hline Varanadi kashayam & $60 \mathrm{ml}$ twice daily before food \\
\hline Vettumaran gulika & $1-0-1$ with kashayam \\
\hline $\begin{array}{l}\text { Guggulupanchapala } \\
\text { choornam }\end{array}$ & $0-0-1$ tsp after food \\
\hline $\begin{array}{l}\text { Guloochyadi kashaya } \\
\text { panajalam }\end{array}$ & 2 litres \\
\hline
\end{tabular}

\section{Procedures Done-}

Local Abhyanga (face and neck) was done with tila tailam with saindhava for 10 minutes, Naadi sweda with dasamoolam kashayam for 10 minutes

followed by virechana nasyam with tulasi swarasam +2 drop honey+l pinch induppu

Done for 7 days $2 \mathrm{ml}, 2.5 \mathrm{ml}, 3 \mathrm{ml}, 3.5 \mathrm{ml}, 3 \mathrm{ml}, 2.5 \mathrm{ml}, 2 \mathrm{ml}$ on consecutive days. (starting by $2 \mathrm{ml}$, increasing by $.5 \mathrm{ml}$ each day)

Daily fresh Tulsi leaves are taken. It is washed properly, dried and crushed. Swarasa is taken by sqeezing. To this 2 drops of honey and a pinch of saindhava is added and is used for nasya procedure.

After nasya -kabala with saindhava jalam and dhoomapana with haridradi varti was given

Lepanam on sinus areas- rasnadi choornam+ jambeera swarasam for 7 days. Patient was advised to spit out the kapha that is coming.

Patient was advised to take rest, not to sit below revolving fan, also not to go outside to avoid direct suns heat. She is advised to take light food. Advised not to sleep during day time also not to get head bath during nasya days. Proper sleep is also ensured.

On Discharge For Three Weeks (phase 2 From 15/6/2019 8/7/2019) (table-2)

\begin{tabular}{|l|l|}
\hline $\begin{array}{l}\text { Dasamoolakatutrayam } \\
\text { kashayam } 60 \mathrm{ml}+1 \text { tsp } \\
\text { vyoshadi vatakam }+ \text { honey }\end{array}$ & in morning before food \\
\hline $\begin{array}{l}\text { Vyaghyadi kashayam } 60 \\
\text { ml+2 pinch bhavana } \\
\text { pippali choornam }\end{array}$ & was given in evening after food \\
\hline Bruhat triphala choornam & 1 tsp bedtime with hot water \\
\hline $\begin{array}{l}\text { Pratimarsha nasya with } \\
\text { anutailam }\end{array}$ & $\begin{array}{l}6 \text { drops each nostril for first } \\
\text { week } \\
\text { 3 drops each nostril for next } \\
\text { two week }\end{array}$ \\
\hline
\end{tabular}

Next One Month (phase 3 From 9/7/2019 - 9/8/2019) (table-3)

\begin{tabular}{|l|l|}
\hline $\begin{array}{l}\text { Sidha lehyam (chitraka } \\
\text { hareethaki }\end{array}$ & 1 tsp twice daly \\
\hline Dasamoolam kashayam & $60 \mathrm{ml}$ twice daily before food \\
\hline $\begin{array}{l}\text { Ksheerabala nasyam } \\
\text { pratimarsam }\end{array}$ & 3 drops each nostril \\
\hline
\end{tabular}

Adviced to practice pranayama

\section{Next One Month (phase 4 From 9/8/2019 - 9/9/2019)}

Indukantham ghritam - 1 tsp with $1 / 2$ tsp vyoshadi vatakam bed time.

\section{Assessment Criteria}

Done on the basis of relief observed in the presenting complaints based on SNOT-22(sinonasal outcome test22).SNOT is a validated questionaire that was developed and validated to assess the burden of CRS symptomatology. (Figure.2)

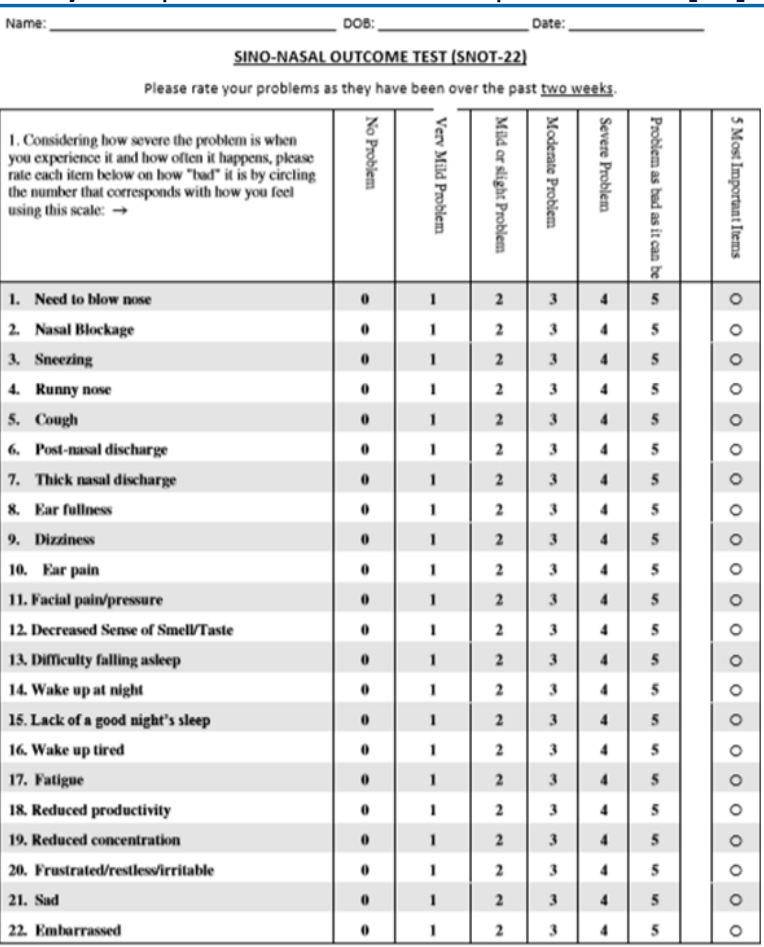

Please mark the most important items affecting your health (maximum of 5 items)

2. Facial pain /pressure is assessed by visual analogue scale (Figure-3)

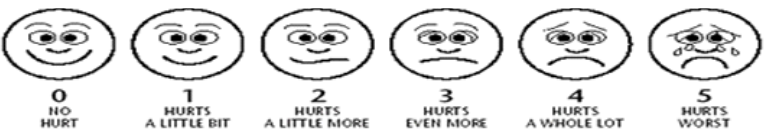

Observations And Result (table-4)

\begin{tabular}{|l|l|l|}
\hline & $\begin{array}{l}\text { SNOT22 } \\
\text { SCORE }\end{array}$ & $\begin{array}{l}\text { VISUAL ANALOGUE } \\
\text { SCALE }\end{array}$ \\
\hline BEFORE TREATMENT & 73 & 4 \\
\hline $\begin{array}{l}\text { AFTER I WEEK OF } \\
\text { VIRECHANA NASYA }\end{array}$ & 27 & 2 \\
\hline AFTER I MONTHS & 15 & 0 \\
\hline AFTER 2 MONTHS & 6 & 0 \\
\hline AFTER 3 MONTHS & 0 & 0 \\
\hline
\end{tabular}

By seven days of treatment main complaints like headache, facial pain, fatigue, congestion of nose got reduced much and SNOT score got considerably reduced from 73 to 27 . Facial pain got reduced from 4 to 2 in visual analogue scale In the second phase, during review it is found that allergic symptoms like sneezing, post nasal dripping got reduced, sense of smell got normal, began to get good sleep. SNOT score also reduced from 27 to 15 . Facial pain which is assessed by visual analogue scale, value got reduced to zero ie. no pain condition.

In the third phase on review, SNOT22 score got down to six. ie. all the complaints got reduced.

\section{DISCUSSION}

Etiological factors for kaphaja sirasoola are sedentary life style, intake of heavy and unctuous food, excessive sleeping, day sleeping, excessive play in water etc. While considering the pathology of chronic rhinosinusitis, it can be explained in different conditions like kaphaja sirasoola, kaphaja pratisyaya and dushta pratisyaya. As it is pratisyayajanya vikara, the doshas involved mainly are kapha and vata. As the disease is chronic and there is stagnation of mucous secretion and loss of muco ciliary clearance, we have to consider that there is obstruction in movement of the vata by kapha avarana.[5] 
In the first phase varanadi kashayam with vettumaran gulika given as kaphamedo hara and it relieves mandagni and is anti-inflammatory in action. Guggulupanchapalam given to relieve infection if any. Goolochyadi panajalam is given to relieve gastric complaints. In the initial phase, there wont be much effect in giving only internal medication, as kapha is in praboota dustaavastha and may be deep seated with srothorodha. It should be removed through the nearest route. So teekshna virechana nasya with tulasi swarasa was administered for its elemination.

Tulsi has qualities like katutikta rasa, ushna veerya, katu vipaka, laghu, rooksha, teekshna guna and krimigna. [6] It is mixed with honey and saindhavam. Saindhavam increases its sookshma quality there by increasing its penetrating power. Madhu and saindhavam has power of kapha vilayana (liquefaction) chedana (separation of adhesion). So they are added to increase the potency. [7,8] As there is no anatomical abnormalities, proper removal of dusta kapha is possible by virechana nasya. Thus better relief is obtained in a short period.

In the 2 nd phase that is for shesha dosha samana, internal medications for allergic symptoms are incorporated on discharge medicine. Dasamoolakatutraya and vyaghyadi kashaya given as they are vatakapha hara in nature. Pratimarsha nasyam with anutailam given for sesha kapha sodhana. After avapeeda nasya there is a chance of getting vata kopa. Taila is vatahara and it never increases kapha due to its ushna property. Taila due to the adherent property of removing malasanga detaches remaining kapha, so anutaila is used here.

Rasayana medications for increasing immunity are given in next phase. Chitraka hareetaki rasayana told in Chakradattam nasadhikaram, dasamoolam kashayam which is tridoshasamana and ksheerabala pratimarsha nasyam (brimhana nasya) is given to strengthen the indriyas and to prevent the recurrence.

In last phase, indukantham ghrita was given to improve overall immunity thereby preventing reccurence and allergic reactions.

3 months treatment was given. Patient was adviced healthy food habits. Patient didn't get complaints by 2 year.

\section{CONCLUSION}

As far as ayurveda is concerned, suddha chikitsa i.e. the pure form of treatment which corrects the pathology and at the same time not creating any sort of side effects is highly important. This study is highly significant in research point of view as much reduction in clinical symptoms was appreciated after the 7 days of nasya treatment itself. After the course of treatment complete remission occurred and there is no recurrence by 2 years. Ayurveda owns a highly Individualized and experience based approach. The medications and panchakarma procedures done in this patient are of immense importance to eliminate vitiated dosha, to remove ama, to correct agni and to regain the patency of srotas. Immunological benefits from these formulations are time tested and hence for its wider usage, much more evidence based reports are to be published. Being a single case study there are many limitations and it can be modified by conducting it in large sample size.

\section{REFERENCES}

1. Dirk Dietz de Loos, Evelijn S. Lourijse,Prevalence of chronic rhinosinusitis in the general population based on sinus radiology and symptomatology march 2019 (pubmed)

2. Rosenfeld RM, Piccirillo JF, Chandrasekhar SS, et al. Clinical practice guideline (update): adult sinusitis. Otolaryngol HeadNeckSurg.2015;152(2 suppl):S1-S39.

3. Heath J, Hartzell L, Putt C, Kennedy JL. Chronic Rhinosinusitis in Children: Pathophysiology, Evaluation, and Medical Management. Curr Allergy Asthma Rep. 2018 May 29;18(7):37.[PubMed]

4. Vagbhata (Arunadatta and Hemadri commentary) Astanga Hridaya .Reprint10,Hari Sadasiva Sastri Paradakara bhishagacharya H, editor. Varanasi: Caukambha orintalia;2019. Uttarasthanam chapter23/10 P 859.

5. Vagbhata (Arunadatta and Hemadri commentary) Astanga Hridaya .Reprint10, Hari Sadasiva Sastri Paradakara bhishagacharya H, editor. Varanasi: Caukambha orintalia; 2019.Uttarasthanam chapter 23/1-3 P 858.

6. Dr.J LN Sastri, Illustrated dravya guna vijnana study of the essential medicinal plants in Ayurveda Varanasi choukhambha orientalia vol2 P-433
7. Vaidya yadavji trikamji acarya, Charaka Samhita( chakrapani commentary) charaka samhita kalpasthanam chapter 1/ 15th sloka.chaukhambha surbharati prakashan,Varanasi.2011,p-654

8. Vagbhata (Arunadatta and Hemadri commentary)Astanga Hridaya .Reprint10, Hari Sadasiva Sastri Paradakara bhishagacharya H, editor. Varanasi: Caukambha orintalia;2019. sootrasthanam chapter 6/143 P 115. 